\title{
The effect of non-toxic endophytes in tall fescue on two major insect pests
}

\author{
A.J. POPAY ${ }^{1}$, J.G. JENSEN ${ }^{1}$ and B.M. COOPER ${ }^{2}$ \\ ${ }^{1}$ AgResearch, Ruakura Research Centre, PB 3123, Hamilton \\ ${ }^{2}$ AgResearch, Kerikeri Research Station, Kerikeri \\ alison.popay@agresearch.co.nz
}

\begin{abstract}
In a choice trial in a glasshouse, infection of tall fescue with the endophyte AR542 significantly reduced feeding by adult Argentine stem weevil (ASW) in the cultivar J esup but not in Advance in comparison with the same cultivars without endophyte. Paddocks of Quantum infected with AR542 that were sampled on two Northland farms consistently had fewer tillers damaged by Argentine stem weevil than equivalent paddocks of endophyte-free (Nil) tall fescue. In comparison to Nil plants, AR542 in Jesup and Advance had significantly fewer plants and tillers damaged by adult black beetle in a glasshouse choice trial. Fewer tillers were also damaged by adult black beetle in Advance tall fescue infected with AR501 and AR502 than in Nil Advance in a small plot field trial at Kerikeri. In a similar trial at Ruakura, the occurrence of adult black beetle and signs of larval damage were high in endophyte-free plots and considerably reduced in endophyte-infected plots. It is concluded that the nontoxic endophytes will lessen damage by black beetle and ASW in a range of tall fescue cultivars and that this is likely to contribute to increases in productivity and persistence of this forage grass.
\end{abstract}

Keywor ds: Argentine stem weevil,black beetle, AR542 endophyte, Neotyphodium, tall fescue

\section{Introduction}

Tall fescue (Festuca anundinacea) is a valuable forage grass in New Zealand, particularly in areas where high summer temperatures and moisture stress limit the growth of perennial ryegrass (Lolium perenne). Tall fescue pastures are capable of higher summer and annual growth than perennial ryegrass (McCallum et al. 1992; Easton et al. 1994) and have a higher clover content than ryegrass pastures infected with Wild-type endophyte (Exton et al. 1996). On a dairy farm in the Waikato, a $16 \%$ increase in milk production was achieved from cows grazing tall fescue compared with a similar herd on ryegrass-based pastures (Milne et al. 1997). In contrast to this, however, McCallum et al. (1992) concluded that tall fescue was unsuitable for use under intensive dairying in Taranaki except in areas prone to dry summers and frequent damage by grass grub (Costelytra zealandica). Tall fescue is slower to establish than ryegrass and requires careful management to realise its full potential.
Although more tolerant of grass grub damage (Kainet al. 1979; East et al. 1980) and less susceptible to Argentine stem weevil (Listronotus bonariensis) damage compared with ryegrass (Prestidge et al. 1986), tall fescue is not immune from damage by these pests. In addition, black beetle (Heteronychus arator), a major pest of grasses in northern North Island areas, can severely limit growth and longevity of tall fescue pastures.

In the south-eastern United States, where tall fescue is the most widely grown cool-season forage grass, infection by the fungal endophyte Neotyphodium coenophialum is considered essential for maintaining pasture productivity and persistence despite the fescue toxicosis it causes in livestock grazing infected pastures. A similar toxicosis can occur in NZ when animals graze on wild tall fescue which is infected with a toxic endophyte. In 2000, a non-toxic Neotyphodium endophyte, AR542 (Max $\mathrm{Q}^{\mathrm{TM}}$ ) was released commercially into the United States market after extensive testing showed that agronomic performance of tall fescue infected with this endophyte was similar to that of tall fescue infected with the Wild-type endophyte without the adverse effects on cattle and sheep caused by the latter (Bouton et al. 2002; Parish et al. 2003). This endophyte AR542 (as Max PTM) is now available to farmers throughout Australasia in several tall fescue cultivars. The effect of AR542 and other non-toxic endophytes on two major insect pests, ASW and black beetle has been evaluated in NZ. This paper reports the results of that research.

\section{Methods \\ Argentine stem weevil}

The effect on adult ASW feeding of the endophyte AR542 in young plants of two cultivars of tall fescue, Advance and Jesup, was assessed in a choice trial with endophyte-free plants, carried out in a glasshouse. An additional three experimental endophytes in Jesup were also evalua ted alongside the AR542 but the results for these treatments will not be reported here. For each replicate, germinated seed of each treatment was planted in rows of eight plants in a seed tray containing commercial potting mix on 29 March 2004. Five replicate seed trays were prepared for each treatment with the placement of treatments randomised within each tray. Spare plants were planted into large 
polystyrene seed boxes containing the same potting mix. All plants were kept in a glasshouse under natural light and with regular watering.

At the end of April, seedlings that had not grown were replaced with spares and all plants were tested for endophyte presence using tissue immunoprint assay (Hahn et al. 2003). On 4 May, 53 adult ASW were released onto each tray and confined using fine nylon net enclosures. The weevils had been collected from the field near Mosgiel in the South Island in October 2003 and J anuary 2004 and maintained in the labor atory.

Adult ASW feeding was assessed on each plant on 19 May, 2 weeks after they were released. Leaf blades on each tiller (2-4 tillers/plant) were visually inspected and each plant assigned a feeding damage score on a scale of $0-5$ where $0=$ no feeding and $5=$ extensive feeding scars present on all leaf blades. An analysis of variance was carried out on untransformed data using a general linear model. Data for plants of each treatment which did not have the appropriate endophyte status were excluded from the analysis.

Field evaluations of ASW larval damage were made on adjacent unreplicated paddocks of tall fescue cv. Quantum without endoph yte or infected with AR542 on two Northland farms. One site near Dargaville, comprising 7 ha each of Nil and endophyte-infected fescue, was sown in spring 2001. The other, at Ohaeawai, west of Kerikeri, was sown at the end of May 2001 and consisted of 5.5 ha of each. In late November 2001 and again in February 2002, 100 tillers were randomly taken from each paddock. These were dissected and ASW larval damage recorded. At the Dargaville site, samples were taken as clumps of tillers which allowed dead tillers to be removed and dissected separately from the live tillers.

\section{Black beetle}

The choice seed tray trial for ASW described a bove was also used to test the response of adult black beetle to AR542 in Jesup and Advance. After completion of the ASW trial, plants that were free from endophyte in the endophyte-infected treatments were removed from each row. Dead shea th mater ial and tillers were removed from remaining plants which were then trimmed to about 7 $\mathrm{cm}$. A liquid fertiliser was applied to each row of seedlings and acetate sheets put in place around the trays to prevent beetles escaping. On May 25, 10 adult beetles, field-collected from Northland over the previous weeks, were released onto each of the five replicate trays. Two weeks later on June 10, the number of damaged and undamaged tillers on each plant was recorded. Damaged tillers were recorded as being either slightly damaged where there were small feeding scars at the base of the tiller or severely damaged where the base of tillers was completely shredded and the tiller was dead or dying.

Field trials with non-toxic endophytes were also sampled for black beetle adult and larval damage. In autumn 1997, small plot field trials of tall fescue were sown at the AgResearch research stations at Ruakura and Kerikeri. Among the treatments in these trials were Advance without endophyte and Advance infected with the non-toxic endophytes AR501 and AR502. There were four replicate plots of each treatment arranged in a randomised block design. Both sites were sampled in autumn 1999. At Ruakura, four spade squares were taken from each of three replicate plots of each treatment and searched for presence of adult black beetle and signs of larval damage ie. presence of tunnelling beneath plants and frass that is characteristic of black beetle larvae. At Kerikeri, a minimum of 30 live tillers were cut at the base from each of the four replicate plots for each treatment and examined for black beetle adult damage. All dead tillers sampled were also examined.

In addition, 70 live tillers were harvested in March 2004 from each of the adjacent AR542 and endophytefree tall fescue paddocks on the Ohaeawai farm. These, plus all dead tillers sampled at the same time, were examined for symptoms of adult black beetle feeding.

Untransformed data on the percentage of plants and tillers damaged in the glasshouse trial were analysed as binomial data using regression analysis with a logit link function which took into account the number of plants and tillers in each treatment. The data from the replicated small plot field trials were analysed using ANOVA.

\section{Results}

\section{Argentine stem weevil}

In the glasshouse trial, endophyte infection levels in Advance with AR542 w ere $67.5 \%$ (27 of 40 plants were infected) and $100 \%$ in Jesup. No endophyte infection was found in Nil treatments of either cultivar. Plants in the Advance AR542 treatment that were endophyte-free were not removed prior to assessment of ASW feeding, but the data for these plants were excluded from the analysis. Adult weevil feeding damage (based only on plants with the correct endophyte status) was significantly less on endophyte-infected tall fescue plants than on endophyte-free, for both cultivars combined $(\mathrm{P}<0.01)$ and for Jesup alone $(\mathrm{P}<0.001)$ (Table 1). Feeding score on Advance AR542 was not significantly less than that on Nil Advance $(\mathrm{P}>0.05)$. There was no significant effect of cultivar itself on weevil feeding.

At the Dargaville site, ASW larval damage was recorded in $13 \%$ of endophyte-free tillers sampled in November and in $8 \%$ of tillers sampled in February. In the February sample, there were also 11 dead tillers and 
Table 1 Argentine stem weevil adult damage (mean feeding score per plant) on two cultivars of tall fescue without endophyte (Nil) or infected with the endophyte AR542.

\begin{tabular}{lccc}
\hline Cultivar & & Nil & \\
\cline { 2 - 3 } & AR542 & Endophyte & SED - \\
\hline Advance & 0.938 & 1.35 & Endophyte 0.185 \\
Jesup & 0.425 & 1.35 & Cultivar 0.185 \\
Mean & 0.682 & 1.35 & Endophyte*Cultivar 0.26 \\
\hline
\end{tabular}

Table 2 Percentage of plants and tillers damaged by adult black beetle given a choice between two cultivars of tall fescue either without endophyte (Nil) or infected with AR542. Total numbers of plants and tillers assessed for damage are given in parenthesis.

\begin{tabular}{llcccc}
\hline \multirow{2}{*}{ Cultivar } & \multicolumn{2}{c}{$\%$ Plants damaged $(\mathrm{N})-$} & & \multicolumn{2}{c}{$\%$ Tillers damaged (N) - } \\
\cline { 2 - 3 } & AR542 & Nil & & AR542 & Nil \\
\hline Advance & $0(27)$ & $58(38)$ & & $0(106)$ & $42(133)$ \\
Jesup & $8(37)$ & $27(40)$ & $3(127)$ & $19(187)$ \\
Mean & $4(64)$ & & $41(78)$ & $2(233)$ & $39(320)$ \\
Average SED & & 6.7 & & & 3.3 \\
\hline
\end{tabular}

9 of these ( $82 \%)$ had been killed by stem weevil larvae. Larval damage to tillers from AR542-infected fescue paddocks was $1 \%$ on both sampling occasions. In the February sample only 3 dead tillers were collected and none of these showed signs of larval damage. Levels of larval damage on the Ohaeawai farm were low with 5\% of Nil tillers sampled in November damaged and only $1 \%$ in February. No damage was found in the samples taken from the AR542-infected pad dock.

\section{Black beetle}

In the glasshouse choice trial, there were far fewer plants and tillers damaged by adult black beetle in the AR542 treatment than in Nil for both cultivars $(\mathrm{P}<0.001)$ (Table 2). There was a significant cultivar*endophyte interaction such that Nil Advance tall fescue suffered significantly more damage (both plants and tillers) than Nil Jesup $(\mathrm{P}<0.001)$, whereas there was no difference in damage between these two cultivars when they were infected with AR542 $(\mathrm{P}>0.05)$. Of the Nil tillers that were damaged in Jesup $(\mathrm{N}=35)$ and Advance $(\mathrm{N}=55), 86 \%$ and $84 \%$, respectively were severely damaged, whereas only one of the four tillers damaged in Jesup AR542 was classed as severely damaged.

In the Kerikeri small plot trial, adult black beetle damage was recorded in $23 \%$ of Nil tillers and $3 \%$ and $7 \%$ of tillers in plots infected with AR501 and AR502 respectively $(\mathrm{P}<0.01)$. In the equivalent trial at Ruakura, the percentage of samples taken which contained adult black beetle was $83 \%$ in Nil, $0 \%$ in AR501 and $17 \%$ in AR502-infected tall fescue ( $\mathrm{SED}=16.67, \mathrm{P}<0.05$ ). Similarly, signs of larval damage were present in $75 \%$ of samples taken in Nil plots but only in $8 \%$ of samples from each of the two endophyte-infected treatments $(\mathrm{SED}=6.8, \mathrm{P}<0.001)$.

In the unreplicated paddocks of tall fescue at Ohaeawai, 23\% of 70 tillers taken in March 2004 from the endophyte-free fescue were damaged by adult black beetle compared with only $1 \%$ of tillers infected with AR542. No dead tillers were among the samples taken from the AR542-infected paddock but six of 10 dead tillers sampled from the Nil paddock were damaged by adult black beetle and a further three by ASW larvae .

\section{Discussion}

Deterrency to adult feeding is the basis of the resistance to black beetle and ASW conferred by many endophytes. Adequate food resources are essential for sustaining adult black beetle survival through autumn and winter and allowing them to lay eggs in spring while deterrency of adult ASW also reduces egg lay and hence damage by the destructive larval stage. These trials have shown that AR542 in the cultivars Jesup and Advance reduces adult black beetle feeding both in the laboratory and in the field. Resistance to adult black beetle from infection by AR542 has also been demonstrated previously in the cultivar Kentucky 31 (Popay 2004). The resistance to adult black beetle was reflected in far fewer signs of larval damage in endophyte-infected plots in the field trial at Ruakura compared with the endophyte-free plots which were almost destroyed by black beetle larval damage during the summer and autumn of 1999.

Laboratory testing also showed that AR542 significantly reduces adult ASW feeding in the cultivar Jesup but the results were less certain for Advance. This may reflect a lower level of the active factors that deter 
ASW in Advance compared with Jesup. Alternatively, weevil behaviour may have been altered in the Advance AR542 treatment by one third of the plants in these rows being endophyte-free, thus giving the weevils a less definitive choice compared with Jesup AR542 where all plants were infected. As the samples taken from the Northland farms indicate, AR542 in Quantum is also effective at reducing ASW larval damage. Whether this is due, at least in part, to metabolites produced by the endophyte acting directly on the larvae, as well as deterring the adults, has yet to be determined. Further work is also needed to demonstrate that there is robust resistance to ASW in Ad vance with AR542 in the field.

The non-toxic endophytes in tall fescue do not produce the ergopeptine alkaloids that are believed to be responsible for fescue toxicosis in livestock in the United States (Hill et al. 1994) but which also deter feeding by adult black beetle (Ball et al. 1997). They do, however, produce derivatives of the loline alkaloids which are known to have broad spectrum activity against several insects (Popay \& Bonos 2004). These metabolites may be responsible for mediating the observed resistance to both black beetle and ASW in tall fescue infected with AR542, AR501 or AR502, but we cannot be sure of this until assays with loline derivatives are conducted on these insects. These endophytes also produce peramine which is a potent deterrent to ASW but which has no effect on black beetle. The concentrations of peramine in tall fescue infected with these endophytes, however, are considerably lower than the concentrations produced by, for example, the AR1 and Wild-type endophytes in ryegrass (D.E. Hume, unpublished data) and may be too low to be biologically active against the weevil.

Endophyte infection of tall fescue increases its productivity and persistence, an effect which, at least partially, can be attributed to a reduction in insect pests, although in the United States the endophyte is also considered to protect its host from abiotic stress such as drought. Here in NZ, both ASW and black beetle are capable of causing damage to tall fescue. In a survey of Roa tall fescue, ASW were present in all pastures with up to $39 \%$ of tillers killed by larvae (Prestidge et al. 1989). Higher yields and plant populations have been measured in tall fescue infected with the endophytes AR501 and AR502 compared with endophyte-free plots in the small plot trial at Kerikeri where black beetle were present (Cooper et al. 2002) and tiller counts taken in March 2004 on the farm at Ohaeawai found nearly twice as many tillers in the paddocks infected with AR542 as in the endophyte-free (B.M. Cooper unpublished data). In New South Wales, dramatic differences in productivity between tall fescue without endophyte or infected with AR542 were measured in both Advance and Quantum and were attributed to severe black beetle larval damage to endophyte-free plots within a year of sowing (Wheatley et al. 2003). Similarly in the Ruakura small plot trial, yield in endophyte-free plots was $316 \mathrm{~kg}$ $\mathrm{DM} / \mathrm{ha}$ compared with 1154 and $1426 \mathrm{~kg} \mathrm{DM} / \mathrm{ha}$ in the AR501 and AR502 plots respectively in May 1999 (D.E. Hume unpublished data) following major black beetle damage during the summer and autumn. In addition to their effects on black beetle and ASW, these non-toxic endophytes in tall fescue can reduce populations of pasture mealybug (Balanococcus poae) (Pennell \& Ball 1999) and the root aphid, Aploneura lentisci (Popay \& Jensen 2005).

\section{ACKNOWLEDGEMENTS}

The assistance of Kathryn Panckhurst with Northland sampling, Neil Cox with sta tistics, Wayne Simpson and Anouck de Bonth with developing immunoblots, Colin Ferguson and Kim Crook for providing the ASW and Vicky Rawnsley for collecting black beetle is gratefully acknowledged. Special thanks also to the farmers, Roger Ludbrook at Ohaeawai and Bob Franklin at Dargaville, on whose properties the field trials were located. This research was funded by the Foundation for Research, Science \& Technology

\section{REFERENCES}

Ball, O.J.-P.; Miles, C.O.; Prestidge, R.A. 1997. Ergopeptine alkaloids and Neotyphodium loliimediated resistance in perennial ryegrass against adult Heteronychus arator (Coleoptera: Scarabaeidae). Journal of Economic Entomology 90: 1382-1391.

Bouton, J.H.; Latch, G.C.M.; Hill, N.S.; Hoveland, C.S.; McCann, M.A.; Watson, R.H.; Parish, J.A.; Hawkins, L.L.; Thompson, F.N. 2002. Reinfection of tall fescue cultivars with non-ergot alkaloidproducing endophytes. Agronomy Joumal 94: $567-$ 574.

Cooper, B.M.; Easton, H.S.; D.E., H.; Popay, A.J.; Baird, D.B. 2002. Improved performance in Northland of tall fescue with a novel endophyte. Proceedings of the Australasian Plant Breeding Conference 12: 379-381.

East, R.; Kain, W.M.; Douglas, J.A. 1980. The effect of grass grub on the herbage production of different pasture species in the pumice country. Proceedings of the New Zealand Grassland Association 41: 105115.

Easton, H.S.; Lee, C.K.; Fitzgerald, R.D. 1994. Tall fescue in Australia and New Zealand. New Zealand Journal of Agricultural Research 37: 405-417.

Exton, P.R.; Dawson, J.E.; Thomson, N.A.; Moloney, S.; Lomas, J. 1996. More summer milk-progress to date. Proceedings of the Ruakura Farmers, 
Conference 48: 34-41.

Hahn, H.; Huth, W.; Schoberlein, W.; Die penbrock, W. 2003. Detection of the endophytic fungi in Festuca spp. by means of tissue print immunoassay. Plant Breeding 122: 217-222.

Hill, N.S.; Thompson,F.N.; Dawe, D.L.; Stuedemann, J.A. 1994. Antibody binding of circulating ergopeptine alkaloids in cattle grazing tall fescue. American Journal of Veterinary Research 55: 419424.

Kain, W.M.; Slay, M.W.; Atkinson, D.S. 1979. Evaluation of grass grub-plant interactions of grasses sown with and without white clover in central Hawkes Bay. Proceedings of the New Zealand Weed and Pest Control Conference 32: 86-91.

McCallum, D.A.; Thomson, N.A.; Thom, E.R. 1992. The place of tall fescue in intensive dairying. Proceedings of the Ruakura Farmers 'Conference 44: 93-97.

Milne, G.D.; Shaw, R.; Powell, R.; Pirie, B.; Pirie, J. 1997. Tall fescue use on dairy farms. Proceedings of the New Zealand Grassland Association 59: 163167.

Parish, J.A.; McCann, M.A.; Watson, R.H.; Hoveland, C.S.; Hawkins, L.L.; Hill, N.S.; Bouton, J.H. 2003. Use of nonergot alkaloid-producing endophytes for alleviating tall fescue toxicosis in sheep. Journal of Animal Science 81: 1316-1322.

Pennell, C.; Ball, O.J.P. 1999. The effects of Neotyphodium endophytes in tall fescue on pasture mealy bug (Balanococcus poae). Proceedings of the
New Zealand Plant Protection Conference 52: 259263.

Popay, A.J. 2004. Response of black beetle (Heteronychus arator), porina (Wiseana cervinata) and grass grub (Costelytra zealandica) to different endophytes in tall fescue. Proceedings of the Australasian Conference on Grassland Invertebrate Ecology 8: 157-163.

Popay, A.J.; Bonos, S.A. 2004. Biotic responses in Endophytic Grasses. pp. 163-185. In: Neotyphodium in Cool-Season Grasses. Eds. Roberts, C.A.; West, C.P.; Spiers, D.E. Blackwell Publishing, Iowa, USA.

Popay, A.J.; Jensen, J.G. 2005. Soil biota associated with endophyte-infected tall fescue in the field. New Zealand Plant Protection 58: 117-121.

Prestidge, R.A.; Badan, D.; van der Zijpp, S. 1986. The effect of Argentine stem weevil on cocksfoot and tall fescue when so wn with ryegrass. Proceedings of the New Zealand Weed and Pest Control Conference 39: 33-37.

Prestidge, R.A.; van der Zijpp, S.; Gault, P. 1989. Effect of Argentine stem weevil on vigour of 'Grasslands Roa' tall fescue under dairying in the Waikato. New Zealand Journal of Agricultural Research 32: 291297.

Whea tley, W.M.; Hume, D.E.; Kemp, H.W.; Monk, M.S .; Lowe, K.F.; Popay, A.J.; Baird, D.B.; Tapper, B.A. 2003. Effects of fungal endophyte on the persistence and productivity of tall fescue at 3 sites in eastern Australia. Proceedings of the 11th Australian Agronomy Conference (CD-ROM). 